\title{
Impact of utilizing semantic maps strategy on the development of English language vocabulary learning for Saudi secondary schools' students
}

\author{
Dr. Abdelrazig Abdelghani Mahil Ibrahim* \\ (ESP)Lecturer-Posha Academy- Kingdom of Saudi Arabia
}

*Corresponding Author: Dr. Abdelrazig Abdelghani Mahil Ibrahim, (ESP)Lecturer-Posha AcademyKingdom of Saudi Arabia

\begin{abstract}
This study aims at investigating the impact of utilizing semantic maps strategy on the development of English Language vocabulary learning for Saudi Secondary Schools' Students. The study adopted a descriptive, analytical and quasi-experimental method. The sample of the study consisted of (20) male teachers in Riyadh city in the first semester of the academic year 2017 - 2018. The study employed a questionnaire as a tool to collect data. The study used (SPSS) program to analyze the data. The findings indicated that semantic mapping technique is more effective than the traditional technique in vocabulary learning. All of the teachers expressed a positive point of views towards the use of semantic mapping. Based on the results of this study the study offers the following recommendations: Curricula designers can integrate various semantic maps in the textbook which will facilitate better comprehension of students. Teachers should encourage using pair work and group work as part of the semantic maps strategy to provide opportunities for meaningful interaction and facilitate vocabulary learning.
\end{abstract}

Keywords: Investigate, Impact, Semantic Maps, Strategy, Vocabulary Learning.

\section{INTRODUCTION}

Vocabulary learning is a vital part of education. Some scholars such as Nation (2001) have viewed vocabulary as the most important component of language learning. Language learning, whether first or second, starts with learning words. Vocabulary learning is an incremental process and never stops in the course of learning and using a language (Thornbury, 2002). So, the more words one knows, the more he/she equips himself/herself with a good body of vocabulary knowledge, and the greater ability he/she will have to express his/her thought in a comprehensive, efficient way (Nation \& Chung, 2009).

Vocabulary, as Brown (2001) states, forms the building block of any language. Vocabulary is "a core component of the language proficiency and provides much of the basis for how well learners speak, listen, and write" (Richards \& Renandya, 2002, p. 255). Without having a comprehensive body of vocabulary and clear-cut strategies for acquiring new vocabulary, learners often fail to fulfill their potentials and may lose their enthusiasm in using opportunities available around them (Richards \& Renandya, 2002).

In the past, vocabulary teaching and learning were often given scant attention in languageprograms, but recently we have witnessed a renewed surge of interest in the nature and the rolevocabulary plays in learning and teaching a language (Richards \& Renandya, 2002). This can be attributed to the fact that traditionally it was believed that vocabulary knowledge can be gained incidentally in an automatic fashion, so attention was given to other aspects of language such as grammar, reading or speaking (Brown, 2001). But nowadays, the status of vocabulary seems to be changing (Richards \& Renandya, 2002).

According to Nation (2001, p.4): "learning vocabulary is a cumulative process and that it must be deliberately taught, learned, and recycled. This is critical for several reasons:

- Learners need to encounter the words in a variety of rich contexts, often requiring up to sixteen encounters, 
- Learners remember words when they have manipulated them in different ways, so variety is essential for vocabulary teaching, and

- Learners forget words within the first twenty-four hours after class, so it is important to follow up a vocabulary lesson with homework that recycles the words" Vocabulary is a very important component within a language as meaning is carried out lexically (Hunt \& Beglar, as cited in Richards \& Renandya, 2002). Learning a language cannot be diminished to, of course, only learning vocabulary but, it is also true that no matter how well the student learns grammar, no matter how successfully the sounds of L2 are mastered, without words to express a wide range of meanings, communication in an L2 just cannot happen in any meaningful way(Brown, 2007).

\subsection{Definition of Vocabulary}

Vocabulary is defined as a word in a specific language or freestanding items of language that have meaning (McCarthy, 1990). Penny Ur (1996) defined vocabulary roughly as "the words we teach in the foreign language" she also suggested that a new item of vocabulary may be more than a single word, a compound of two or three words ( e.g. post office mother- in- law) and multiword idioms (e.g....call it a day )".

Graves (2000, as cited in Omer, 2017) defines vocabulary as the entire stock of words belonging to a branch of knowledge or known by an individual. He also states that the lexicon of a language is its vocabulary. Which includes words and expressions Krashen (1998, as cited in Omer, 2017) extends Graves' definition further by stating that lexicon organizes the mental vocabulary in a speaker's mind. An individual's mental lexicon's is that person's knowledge of vocabulary (Krashen, 1998, as cited in Omer, 2017). Miller (1999, as cited in Omer, 2017) states that vocabulary is a set of words that are the basic building blocks used in the generation and understanding of sentences.

According to Gardenor, (2009, as cited in Omer, 2017), Vocabulary is not only confined to the meaning of words but also includes how vocabulary in a language is structured: how people use and store words and how they learn words and the relationship between words, phrase, categories of words and phrases (Graves, 2000, as cited in Omer, 2017)

\subsection{Vocabulary Teaching}

Traditionally, vocabulary has not been taught in particular subject, but has been taught within lesson of speaking, listening, reading and writing. During the lesson, students use their own vocabulary and are introduced to new words provided by the teacher and classmates which they apply to classroom activities. According to Allen (1983), all experienced language teachers confirm the important role of words and know that lacking of them leads to feeling of insecurity; on the other hand, the teachers' attitude toward teaching vocabulary and the classroom techniques varies enormously. Different techniques are used by teachers, such as teaching the words: through lists, translation, synonyms, antonyms, contexts, realia, and so on. Some teachers believe before teaching vocabulary to their students, they should have been taught the grammar of the foreign language. Therefore, they give little or no attention to vocabulary.

Vocabulary teaching should be part of the syllabus, and taught in well planned and regular basis. (Mora 2008 as cited in Rahma, 2016) states that vocabulary teaching should be based on learner generated word meanings. It is supported by Robb (2000) who stated that vocabulary study before, during, and after reading should be integrated into the curriculum. Learner involvement increases understanding and memory; thus, when students use their experience and background knowledge to define words, they learn better. The words serve as labels for concepts and students associate words to larger vocabulary and experiences. Nation (1990,p.18) states that there are three things that the teacher should know when he/she teaches vocabulary, the teacher teaches the form of the words, the meaning of the words and the use of the words. That's all that the students should know when they learn a vocabulary. From statement above, the researcher assumes that in teaching vocabulary, teachers should choose appropriate technique for students in learning process become more interesting.

\subsection{Concept of Semantic Maps}

Rubin, (1993, p.79, cited in Omer, 2017) states that Semantic mapping is a technique for organizing information it helps to give structure or order. It helps people to see the relationship among concepts, 
and it shows the various ways that information can be organized and categories. While Broomley, (1992, p.218, cited in Omer, 2017) explains that a semantic maps or web is a graphic representation of categories of information and their relationship to each other.

Heimlish, J. \& Pittelman, S. V (1986, p.276, cited in Omer) explained that a semantic map is one type of graphic organizer. It helps students visually organize and graphically show the relationship between one piece of information and another. This strategy has been identified by researchers as an excellent technique for increasing activity; semantic mapping can be used to activate prior knowledge and to introduce key vocabulary words. As post reading activity, words, categories, and new concepts can be added to the original maps enhance understanding.

Semantic mapping is a process for constructing visual displays of categories and their relationships. It is a categorical structuring of information in graphic form. It is an approach leading students to relate new words to their own experiences and prior knowledge. Semantic maps as Jonassen (1993, p.98) indicates "are type of graphic organizers that visually represent relationships among categories of concepts. Figure (1) displays the structure of a semantic map. They include a key concept, or main idea, with categorized concepts related to the key concept. The categories related to the central concept and the associations among words are indicated visually in a diagram or map.

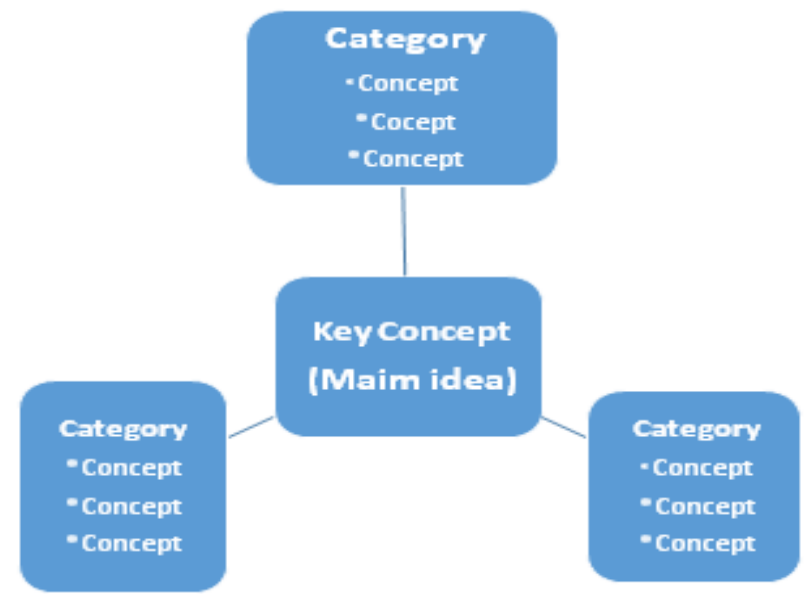

Figure 1. The Structure of Semantic Maps

A teacher can take one key word, example: "Water", and develop categories and subcategories of words and related words. Students can add to the map as they read.

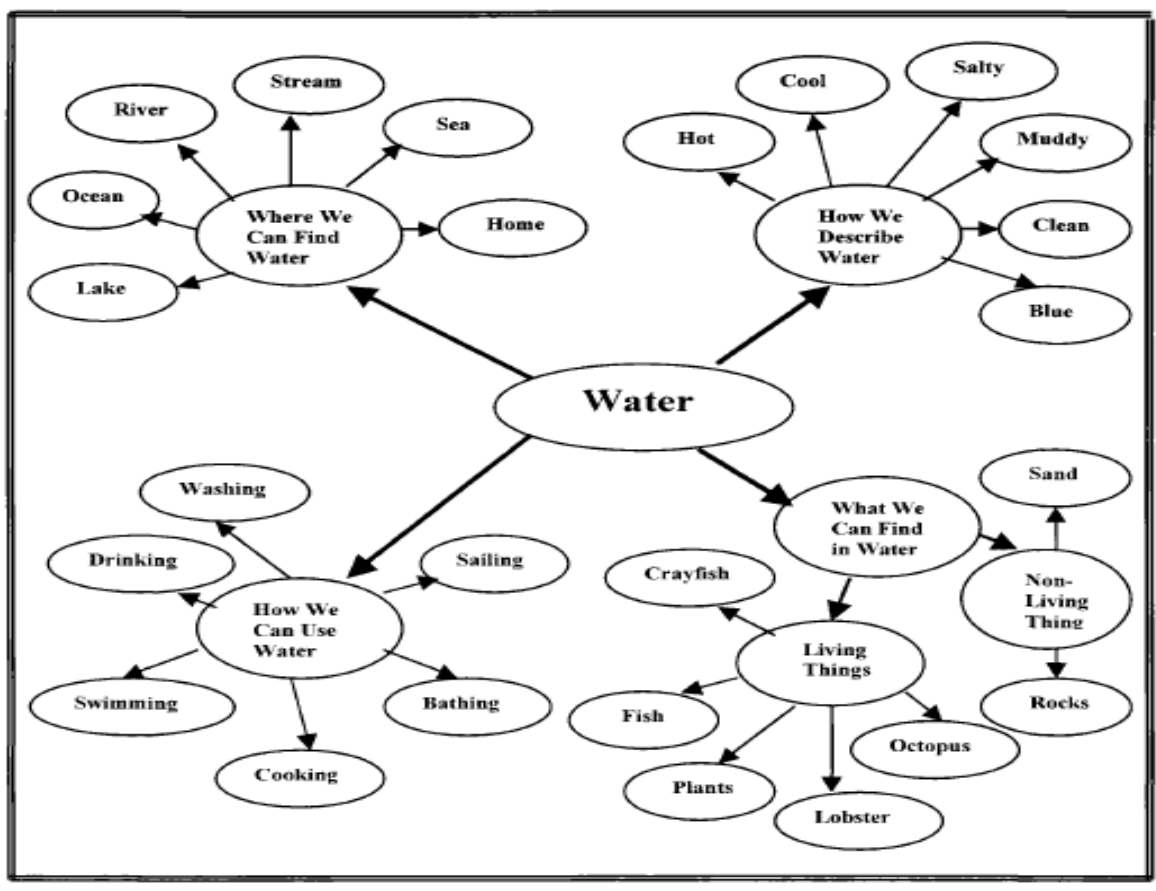


Impact of utilizing semantic maps strategy on the development of English language vocabulary learning for Saudi secondary schools' students

\subsection{Definitions of Semantic Maps}

Developments in "lexical semantics" have prompted the development of the "semantic field theory", "semantic networks" or "semantic grids" strategies which organize words in terms if interrelated lexical meanings. The "semantic field" theory suggests that the lexical content of a language is best treated not as a "mere aggregation of independent words" but as a collection of interrelating networks or relations between words (Stubbs, cited in Amer, 2002). It is noteworthy that words may be grouped together (related to each other) according to different criteria. Animals, for example, may be grouped in terms of physical features; they may be grouped in terms of nonphysical features such as pet, wild, food, etc. (Gairns and Redman, 1986).

Semantic elaboration consists of a series of techniques as semantic feature analysis, ordering, pictorial schemata and semantic mapping (Ellis, 1995; Sokmen, 1997). Semantic mapping and semantic feature analysis draw learners' prior knowledge and use discussion to elicit information about word meanings. Semantic feature analysis is similar to semantic mapping, with theexception that it uses a grid rather than a map as graphic display. Following examples will illustrate the two techniques.

Feature 1. Semantic feature analysis for "means of transport” (Neisel, 2000)

\begin{tabular}{|c|c|c|c|c|c|c|c|c|}
\hline $\begin{array}{l}\text { Means of } \\
\text { transport }\end{array}$ & $\begin{array}{c}\text { One } \\
\text { wheeled }\end{array}$ & $\begin{array}{c}\text { Two } \\
\text { wheeled }\end{array}$ & $\begin{array}{c}\text { Four } \\
\text { wheeled }\end{array}$ & $\begin{array}{c}\text { Foot } \\
\text { powered }\end{array}$ & $\begin{array}{c}\text { Motor } \\
\text { powered }\end{array}$ & $\begin{array}{c}\text { On } \\
\text { land }\end{array}$ & $\begin{array}{l}\text { In the } \\
\text { water }\end{array}$ & $\begin{array}{c}\text { In the } \\
\text { air }\end{array}$ \\
\hline Bicycle & - & + & - & + & $?$ & + & - & - \\
\hline Car & - & - & + & - & + & + & - & - \\
\hline Boat & - & - & - & $?$ & + & - & + & - \\
\hline Plane & - & - & - & - & + & - & - & + \\
\hline Unicycle & + & - & - & + & - & + & & - \\
\hline Motorbike & - & + & - & - & + & + & - & - \\
\hline
\end{tabular}

“+” for positive examples; “-” for negative examples, “?” for items which may be true in certain circumstance.

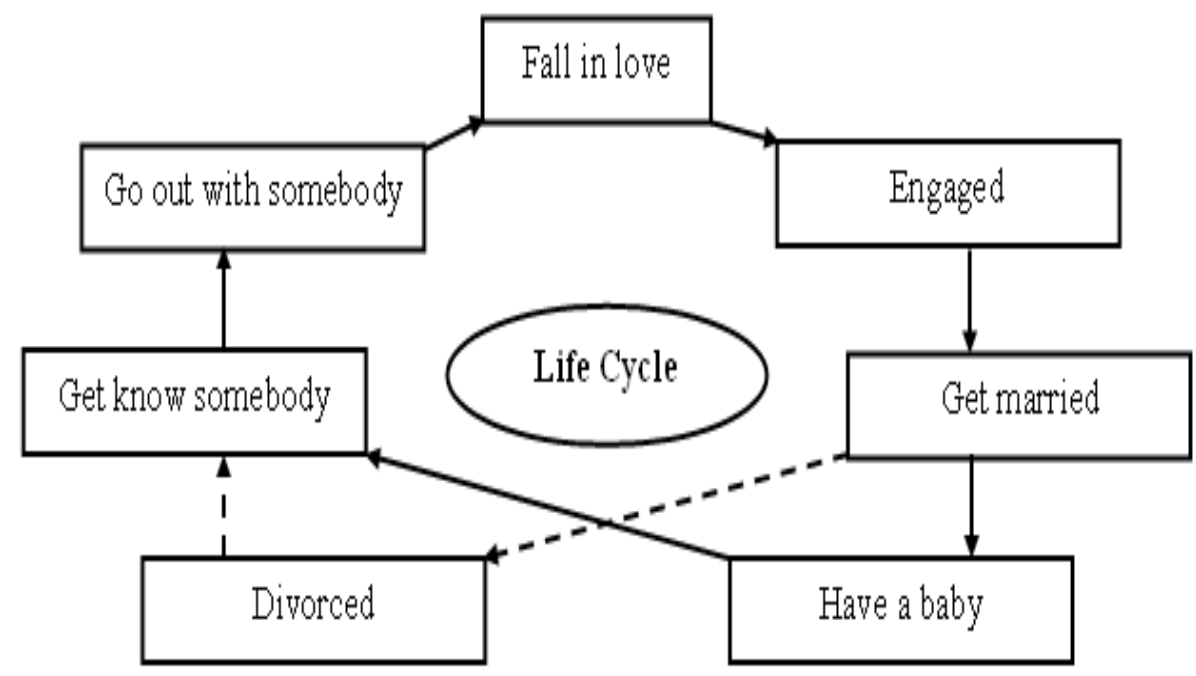

Feature 2. Semantic mapping for "human life circle" (Gairns and Redman, 1986)

Semantic elaboration focuses on word meaning association attached on words. Words appear to be organized into semantically related sets in mind and thus the associations attached to a word will affect the way that it is stored in the brain. Furthermore, knowing a range of association for a word helps understand its full meaning and helps recall the word form or its meaning in appropriate context (Nation, 2001).

Semantic mapping generally refers to brainstorming associations which a word has and then diagramming the results (Sokmen, 1997). Johnson, Pittelman and Heimlich (1986) described semantic mapping as "categorical structuring of information in graphic form". Semantic mapping is one of word association techniques. It is defined as a technique to make arrangement of words into a diagram, which has a key concept at the centre or at the top, and related words and concepts linked to the key concept by means of lines or arrows (Gairns and Redman, 1986). 


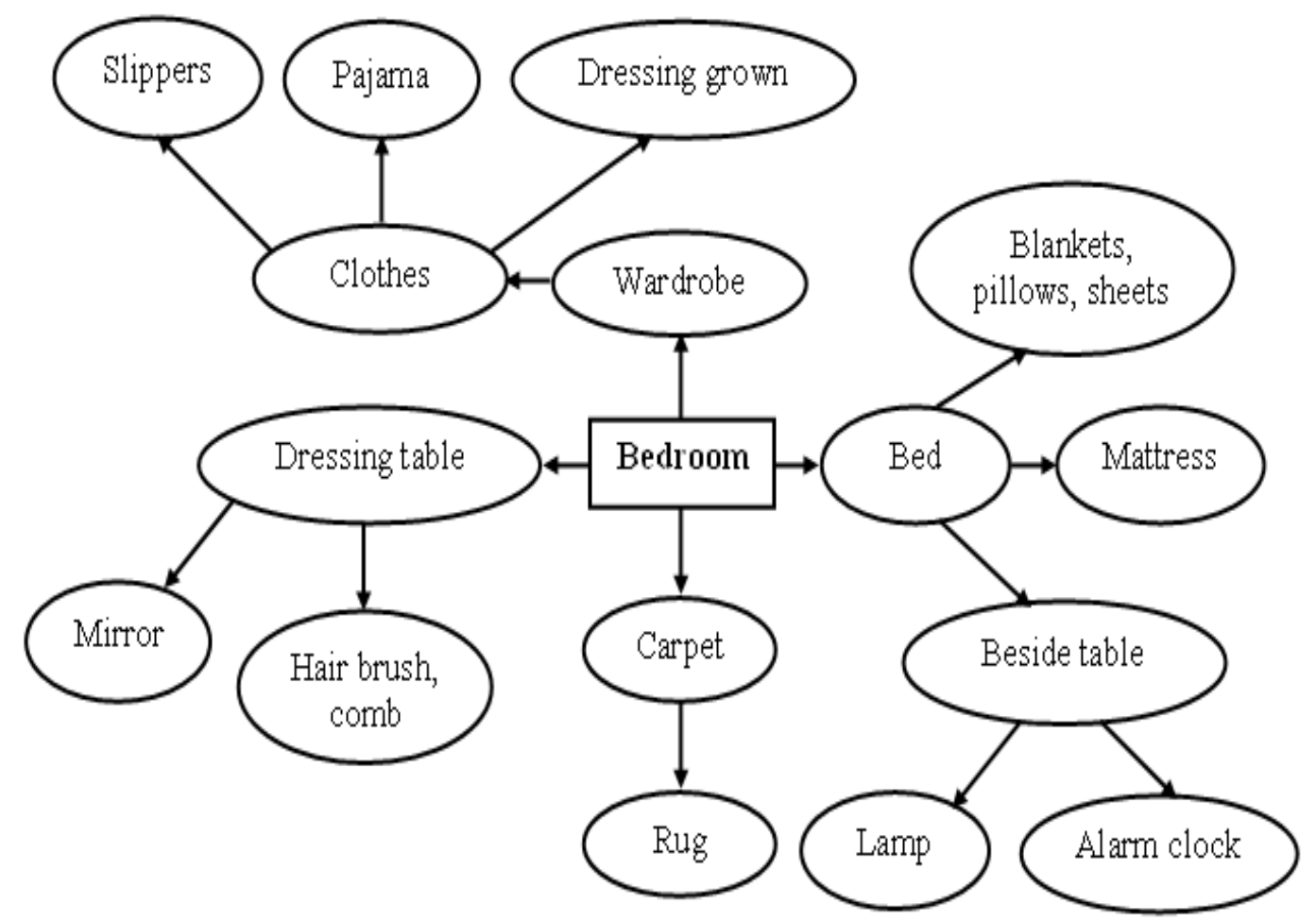

Feature 3. Items in bedroom (Gairns and Redman, 1986)

\subsection{Teaching Vocabulary via Semantic Mapping}

Richard and Renandya (1986) states that one of the other interesting techniques that teacher can use in teaching vocabulary is semantic mapping. This technique incorporates a variety of other memory strategies, they are grouping, using imagery, and associating or elaborating, also this technique is valuable for improving both memory and comprehension of a new word, even enrich their vocabulary. In semantic mapping activity there is no single "right answer", because students just asked to categorize the target word that the teacher has given and then they have to find some new words in each category from what theylabeled.

The teaching learning process itself beginning with explaining and modeling the procedure of how to construct a semantic map, it means the teacher explain that to develop a wide knowledge of words. Because we learn words best by using them in many different context but still in a range of a topic they learnt. So, the teacherbegins the study by mapping the word. Next step is the teacher provides a guided practice when the teacher encourages students to make a semantic map. The teacher walks the class through the construction of a semantic map for the words.

Students discuss the target word (some word that given by teacher). Get them to bring a dictionary in the next meeting if the students seem difficult to comprehend and categorize the words at the first meeting. Third, the teacher establishes a routine for sharing the student's result of their semantic map. Then, encourage them to use the words in a sentence and for this study the writer get them to make a description sentence from word and rule of making a description sentence that they have learnt before. Last, do the review for each meeting is important to establish they readiness for the new semantic mapping which they are going tomake at that time.

In line with the wide explanation above of what is semantic mapping and how to use semantic mapping in teaching and learning vocabulary, the writer is hoped that semantic mapping could help the teacher to answer the students' problem in learning English vocabulary and also could proof this study if semantic mapping can increase students' vocabulary beside facilitate the students to memorize the word in the students' course.

\section{Procedures of teaching vocabulary using semantic mapping technique}

Here are some procedures of teaching vocabulary through semanticmapping: follows: 


\section{Pre-activity}

- Teacher greets the students.

- Teacher checks the students' attendance list.

- Teacher tells the material which is going to be discussed.

\section{While activity}

- Teacher gives the students a narrative text.

- Teacher asks students to look for the meaning of the bold words in dictionary.

- Teacher asks the students to pronounce the words after the teacher.

- Teacher brain storm the students schemata about the words by asking some questions based on the words given. For example:

$>$ What is in your mind when you heard the word "beautiful"?

$>$ Can you mention the synonyms of beautiful?

- Teacher introduces the map to the students by drawing a map as picture of what they need to know to understand a new word (bold words).

Teacher demonstrates the use of the map by putting general, common term in the central box (beautiful).

- Teacher asks students to suggest words or phrases to put in other boxes

- Teacher has them give the definition of the common term in the central box.

- Teacher provides the students with sentences each containing a new word.

\section{E.g.: My sister is beautiful.}

That beautiful woman is my teacher.

- Teacher encourages students to refer the dictionary, encyclopedia or otherreference books for help in completing the map.

- The map might be like this:

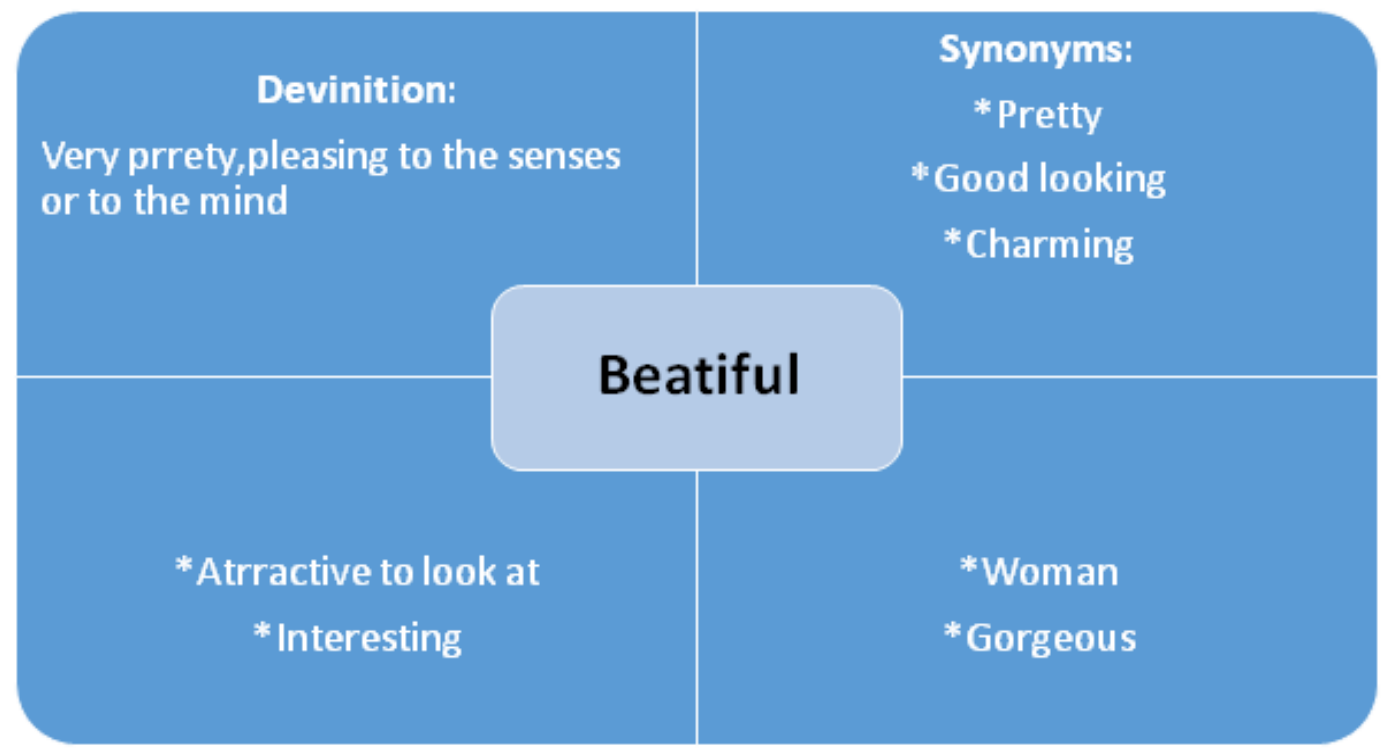

Teacher divides the class in to some groups consisting two students in eachgroup.

- Teacher has them to complete the map.

- After the students finished got the semantic mapping words, teacherdistributes the quiz. The teacher provides worksheet in the form of match theword with picture 


\section{Post activity}

- Teacher delivers the summary of the lesson by asking:

$>$ What kind of vocabulary have you got today?

$>$ Mention some words you have got!

- Teacher answers the students' question, if any, clearly.

- Teacher closes the meeting.

\section{Statement of the Problem}

Vocabulary learning has sometimes become an obstacle for EFL learners. According to the researchers' classroom observations, Saudi students have encountered this problem in their endeavor to learn the English vocabulary. Therefore, the present study is conducted in an attempt to solve EFL Saudi students' problems through teaching them the semantic mapping method as an innovative strategy that may improve the learners' vocabulary in English reading classes.

\section{SignifiCANCE OF THE STUdy}

The significance of this study will be of great value for the following reasons:

- The results of this study will enrich the theory of teaching vocabulary through semantic mapping.

- In addition to that, the results can help the English teachers facilitate the students' learning vocabulary

- The results of this study also can be used as a reference for the researchers who want to conduct researches in the area of English language teaching in general and in teaching vocabulary by using semantic mapping in particular.

\section{OBJECTIVES OF THE STUdY}

The Aims of the study are as follows:

- To investigate whether semantic maps can help the students to acquire vocabulary effectively or not.

- To identify teachers perspective about teaching vocabulary through semantic maps.

\section{QUESTIONS OF THE STUDY}

This study attempts to answer the following question:

- Is teaching vocabulary to Saudi Secondary School's students via semantic maps strategy more effective than using the traditional method?

- To what extent semantic maps can help students to be aware of vocabulary knowledge?

\section{LimitaTions OF THE STUDY}

- The study will be limited to the English Language teachers in Riyadh city and the sample will be (30) teachers through academic year (2017-2018).

- The instrument of the study which is going to be used is the questionnaire to the English teachers in Riyadh city.

\section{Methodology OF THE STUdY}

\subsection{Study Design}

This is an analytical study and its objective is to investigate the impact of using semantic maps strategy on the development of English Language vocabulary learning for Saudi secondary schools' students.

\subsection{Population of the study}

The population of the current study consists of all English Languages in the first semester of the academic year 2017/2018 in Riyadh city. 
Impact of utilizing semantic maps strategy on the development of English language vocabulary learning for Saudi secondary schools' students

\subsection{Sample of the study}

The sample used for this study is limited to level (20) teachers chosen randomly among the English Language teachers in Riyadh city.

\subsection{Data collection}

This study aimed at investigating the impact of using semantic maps strategy on the development of English Language vocabulary learning for Saudi secondary schools' students. Therefore, the following two questions as an attempt to investigate and solve this problem were raised

- Is teaching vocabulary to Saudi Secondary's School via semantic mapping strategy more effective than using the traditional method?

- To what extent semantic mapping helps students to be aware of vocabulary knowledge?

\subsection{Instruments of the study}

In order to collect reliable data, a questionnaire was employed in this study.

\subsection{Validity of the Questionnaire}

In order to ensure the validity of the test was shown to a panel of three university professors. The final form of the test was drawn out after taking their comments, opinions and advices into consideration.

\subsection{Reliability of the Questionnaire}

The current study used a questionnaire as a tool to collect the data (see Appendix (1) for a full copy of the survey) to evaluate teachers' perspectives about teaching vocabulary through semantic maps. The questionnaire contains 10 statements such as "Semantic Maps improves the students' logic." or "Semantic Maps help the students retain the words better". The scale respondents will rate the 10 statements on a Likert scale ranging from (strongly agree $=5$ ) to (strongly disagree $=1$ ). This rating scale was developed by Likert in 1932, and it is considered one of the most common techniques that used by researchers to measure attitudes and perceptions toward given issues (Antonak \& Larrivee, 1995).

\section{Reliability of the Scale:}

When using Likert-type scales it is very important to calculate and report Cronbach's alpha coefficient for internal consistency reliability for any scales or subscales one may be using.

Table 1. Internal Consistency and Reliability of the Scale

\begin{tabular}{|l|c|c|}
\hline & $\begin{array}{c}\text { Item-Total } \\
\text { Correlation }\end{array}$ & $\begin{array}{c}\text { Cronbach's Alpha if } \\
\text { Item Deleted }\end{array}$ \\
\hline $\begin{array}{l}\text { 1. Semantic Maps is a good teaching technique for reviewing } \\
\text { vocabulary lesson. }\end{array}$ & $0.848^{* *}$ & .736 \\
\hline $\begin{array}{l}\text { 2. The traditional presentation of vocabulary list is found to be not } \\
\text { effective in developing vocabulary learning among secondary } \\
\text { school students if compared with semantic maps strategy. }\end{array}$ & $0.839^{* *}$ & .742 \\
\hline $\begin{array}{l}\text { 3. Semantic Maps can help students remember the words grouped in } \\
\text { semantic sets for a longer time. }\end{array}$ & $0.862^{* *}$ & .737 \\
\hline 4. The grouping helps students remember the related things. & $.362^{*}$ & .782 \\
\hline 5. Semantic Maps help the students retain the words better. & $.822^{* *}$ & $.7371^{* *}$ \\
\hline $\begin{array}{l}\text { 6. Semantic maps assume that learners can easily acquire a large } \\
\text { vocabulary size. }\end{array}$ & $.909^{* *}$ & .718 \\
\hline 7. Semantic Maps improves the students' logic. & $.643^{* *}$ & .774 \\
\hline $\begin{array}{l}\text { 8. Semantic maps lead students to relate new words to their own } \\
\text { experiences and prior knowledge }\end{array}$ & 0.013 & .816 \\
\hline 9. Semantic Maps help the students recall the words more easily. & 0.332 & .786 \\
\hline $\begin{array}{l}\text { 10. It is easier to remember words if they are grouped than learning } \\
\text { unrelated words. }\end{array}$ & $\mathbf{N ~ o f ~ I t e m s ~}$ & Cronbach's Alpha \\
\hline \begin{tabular}{l} 
Reliability (Cronbach's Alpha) \\
\hline
\end{tabular} & 10 & 0.782 \\
\hline
\end{tabular}



for Saudi secondary schools' students

$$
\text { ** Significant at level } 0.01 \quad * \text { Significant at level } 0.05
$$

To assess the reliability of the instrument of this study, Cronbach's coefficient alpha which is the most commonly method used to compute the internal consistency reliability (Leech et al., 2005). In this study, Cronbach's alpha was used to assess consistency of the construct. As shown in Table 1 the coefficient of the scale is 0.782 which indicated a high level of reliability, so this instrument is suitable to be used for the purposes of the study. On the other hand, Alpha if Item deleted represents the scale's Cronbach's alpha reliability coefficient for internal consistency if the individual item is removed from the scale. In using the above information, removing items 9 and 10 resulted in an increase in Cronbach's alpha from 0.782 to 0.816 .

\subsection{Population of the Questionnaire}

The populations identified for this study are all teachers in Saudi secondary schools setting. The sample is (30) male teachers and aged 20 to 60 years. The sampling method used was convenience sampling. The advantage of convenience sampling is that it is simple to select individuals to participate. The teacher who participated in this study are qualified teacher with the proper certifications.

\subsection{Procedure of the Questionnaire Distribution}

The questionnaire was distributed by hand randomly to (30) English Language teachers atSecondary Schools in Riyadh city. It consisted of 10 items. The study participants were asked to response for the 10 statements according to their point of view by choosing from; strongly agree, agree, uncertain, strongly disagree, and disagreetoshow their perspectivesabout the effectiveness of semantic mapping strategies invocabulary learning. At the end the researcher thanked all the participants for their cooperation.

The researcher used the Statistical Package for Social Sciences (SPSS) and analyzed the data of the questionnaire.

\subsection{Data Analysis}

Statistical analyses were conducted using IBM SPSS Statistics 20 for Windows, Descriptive statistics were performed. Frequencies and percentages were calculated for the statements of the questionnaire in addition to the means and standard deviations (SDs) for continuous variables.

Reliability was tested using Cronbach`s alpha coefficient. Pearson correlations for internal consistency.

\subsubsection{Criterion of the scale:}

For each of the scale items, a transmutation equivalent was designed, with an equal interval of 0.80 , such that the resultant means of the items may fall under the following categories:

- $<1.80$ - Strongly Disagree;

- $1.80-<2.60-$ Disagree;

- $2.60-<3.40-$ not sure

- 3.40-<4.20 -Agree;

- 4.20 -5 - Strongly Agree.

7.10.2 Results:

This section presents the data from the structured questionnaire which applied to thirty English teachers. The results will present in categories corresponding to our research questions:

\section{General Information of the participants}

The general information of the teachers who participated in the current study consisted of three information, these information includes: age, academic qualification, and teaching experience. As we mentioned before that 30 filled consented questionnaire were collected from the study sample all of them were males. As shown in table (1), the results showed that half of the study participants aged 
Impact of utilizing semantic maps strategy on the development of English language vocabulary learning for Saudi secondary schools' students

40 to 49 years, while (33.3\%) of the participants in age of 20 to 39 years. $16.7 \%$ of the study participants exceeded the age of fifteen. Regarding academic qualification of the study participants, the majority of them hold BA degree (86.7\%) and $13.3 \%$ hold Master degree. In addition, the results showed that most of the study participants have long years of experience in teaching $(66.7 \%)$ followed by those who have five years of experience (30.0\%), while only $3.3 \%$ of the them have two years of experience.

\begin{tabular}{|c|c|c|c|}
\hline \multicolumn{2}{|c|}{ Variables } & \multirow[t]{2}{*}{ Freq. } & \multirow[t]{2}{*}{ Percent } \\
\hline Age & & & \\
\hline & $20-29$ & 4 & 13.3 \\
\hline & $30-39$ & 6 & 20.0 \\
\hline & $40-49$ & 15 & 50.0 \\
\hline & $50-60$ & 5 & 16.7 \\
\hline \multicolumn{4}{|c|}{ Academic qualification } \\
\hline & $\mathrm{BA}$ & 26 & 86.7 \\
\hline & MA & 4 & 13.3 \\
\hline \multicolumn{4}{|c|}{ teaching experiences } \\
\hline & More than ten years & 18 & 60.0 \\
\hline & Ten years & 2 & 6.7 \\
\hline & Five years & 9 & 30.0 \\
\hline & Two years & 1 & 3.3 \\
\hline
\end{tabular}

\subsubsection{Research Questions:}

- Is teaching vocabulary to Saudi Secondary School's students via semantic maps strategy more effective than using the traditional method?

- To identify teachers perspective about teaching vocabulary through semantic maps.

Concerning the data in table (1) which show the teachers' perspective about teaching vocabulary through semantic maps, and by assuming the participants were aware about the two strategies (semantic maps and the traditional method) the results from the questionnaire indicated that the teachers had positive opinions towards the use of semantic mapping $(\mathrm{M}=4.65, \mathrm{SD}=.38)$, the results showed that all of the teachers expressed their positive point of views towards the use of semantic mapping. This result indicates a perfect agreement to the efficiency of using semantic maps strategy in teaching vocabulary to Saudi Secondary School's students.

Table 3. Descriptive Statistics for teachers' perspective about teaching vocabulary through semantic maps

\begin{tabular}{|c|c|c|c|c|}
\hline & Statements & Mean & SD & Rank \\
\hline 1 & $\begin{array}{l}\text { Semantic Maps is a good teaching technique for reviewing vocabulary } \\
\text { lesson. }\end{array}$ & 4.77 & .43 & 5 \\
\hline 2 & $\begin{array}{l}\text { The traditional presentation of vocabulary list is found to be not effective } \\
\text { in developing vocabulary learning among secondary school students if } \\
\text { compared with semantic maps strategy. }\end{array}$ & 4.83 & .38 & 2 \\
\hline 3 & $\begin{array}{l}\text { Semantic Maps can help students remember the words grouped in } \\
\text { semantic sets for a longer time. }\end{array}$ & 4.80 & .41 & 4 \\
\hline 4 & The grouping helps students remember the related things. & 4.87 & .43 & 1 \\
\hline 5 & Semantic Maps help the students retain the words better. & 4.73 & .45 & 7 \\
\hline 6 & $\begin{array}{l}\text { Semantic maps assume that learners can easily acquire a large vocabulary } \\
\text { size. }\end{array}$ & 4.83 & .46 & 3 \\
\hline 7 & Semantic Maps improves the students' logic. & 3.83 & 1.29 & 9 \\
\hline 8 & $\begin{array}{l}\text { Semantic maps lead students to relate new words to their own } \\
\text { experiences and prior knowledge }\end{array}$ & 4.27 & .98 & 8 \\
\hline
\end{tabular}


Impact of utilizing semantic maps strategy on the development of English language vocabulary learning for Saudi secondary schools' students

\begin{tabular}{|l|l|c|c|c|}
\hline 9 & Semantic Maps help the students recall the words more easily. & 4.77 & .50 & 6 \\
\hline 10 & $\begin{array}{l}\text { It is easier to remember words if they are grouped than learning unrelated } \\
\text { words. }\end{array}$ & 4.83 & .46 & 3 \\
\hline
\end{tabular}

In brief,have a look at the mean scores of the participants towards the statements regarding teachers' perspective about teaching vocabulary through semantic maps in table (1), it can be observed that there is a difference in the participants' agreement on these statements. As shown in the figure below the mean score of the statement (The grouping helps students remember the related things) is 4.87 , which was the highest one. Group work can be an efficient way to encourage students, promote active learning and increase key critical-thinking, communication and decision-making skills. However without careful arrangement and facilitation, group work can annoy students and teachers and sense like a misuse of time. By using these ideas can help employ group work effectively in the classroom. On the other hand the mean score of the statement (Semantic Maps improves the students' logic) is 3.83 which was lowest one. In fact, the memory strategy instruction (semantic mapping) did result in the participants' vocabulary learning more than improves their logic in spite that semantic mapping can improve students' logic by giving them the opportunity to draw as many branches in the maps as possible, however the effect of traditional direct translation is less than the semantic mapping.

Furthermore, it was found that certain types of semantic maps were more effective not only on reading comprehension performance but also on fasterreaction time.

\subsubsection{Inferential Statistics:}

\section{Differences in teachers' perspective about teaching vocabulary through semantic maps regarding age, academic qualification and teaching experience:}

As shown in table (4) that there were no significant differences in teachers' perspective about teaching vocabulary through semantic maps regarding age, academic qualification and teaching experience $(\mathrm{P}>.05)$.

Table 4. Differences in teachers' perspective about teaching vocabulary through semantic maps regarding age, academic qualification and teaching experience:

\begin{tabular}{|c|c|c|c|c|c|}
\hline & $\mathbf{N}$ & Mean & SD & $\mathbf{F}$ & Sig. \\
\hline \multicolumn{6}{|l|}{ Age } \\
\hline $20-29$ & 4 & 4.80 & .22 & \multirow{4}{*}{.256} & \multirow{4}{*}{.857} \\
\hline $30-39$ & 6 & 4.60 & .30 & & \\
\hline $40-49$ & 15 & 4.63 & .41 & & \\
\hline $50-60$ & 5 & 4.68 & .50 & & \\
\hline Academic Qualification & & & & $\mathbf{t}$ & Sig. \\
\hline $\mathrm{BA}$ & 26 & 4.63 & .39 & \multirow{3}{*}{.896} & \multirow{3}{*}{.496} \\
\hline MA & 4 & 4.78 & .21 & & \\
\hline \multicolumn{4}{|l|}{ Teaching experience } & & \\
\hline More than ten years & 18 & 4.62 & .44 & \multirow{4}{*}{.272} & \multirow{4}{*}{.845} \\
\hline Ten years & 2 & 4.85 & .21 & & \\
\hline Five years & 9 & 4.67 & .29 & & \\
\hline Two years & 1 & 4.80 &.- & & \\
\hline
\end{tabular}

$P>.05$

In this study, the results indicated that the research questions were confirmed by the inferential statistics, that using the semantic mapping is an effective way in enabling the students to achieve greater progress in vocabulary learning. The findings were not only reliable with the literature review however, as well supportive of the research on using the semantic mapping conducted previously. 
This can be as a guide to the implication that the semantic mapping can develop Saudi Secondary Schools' Students vocabulary retention and is talented to vocabulary teaching and learning.

\subsubsection{Recommendations:}

In the light of the above findings the study recommended that:

- Curricula designers can integrate various semantic maps in the textbook which will facilitate better comprehension of students.

- Teachers should encourage using pair work and group work as part of the semantic maps strategy to provide opportunities for meaningful interaction and facilitate vocabulary learning.

Curricula designers can integrate various semantic maps in the textbook which will facilitate better comprehension of students.

\section{CONClusion}

In conclusion, although there are different techniques in the presentation of target vocabulary items at different stages of foreign language learning, not a certain technique seems to have gained general acceptance among language teachers and learners. It is impossible to say that one technique is completely adequate or inadequate in teaching and learning vocabulary items in foreign language and also it may be wrong to use merely one technique at all stages. Although semantic mapping has been found as an effective technique for learning target vocabulary, teachers and learners can also make use of other additional techniques for vocabulary teaching.

\section{REFERENCES}

[1] Allen, V.F (1983).Techniques in Teaching Vocabulary. New York: Oxford University.

[2] Amer, A. (2002). Advanced vocabulary instruction in EFL. In Nguyen Ngoc Thuy, Viet Nam .Retrieved from: http://www.litu.tu.ac.th/journal/FLLTCP/Proceeding/628.pdf

[3] Brown, D. (2001). Teaching by principles: An interactive approach to language pedagogy. New York: Longman Pearson Education Company.

[4] Brown, D. (2007). Principles of language learning and teaching (5th ed.). New York: Longman Pearson Education Company.

[5] Ellis, N. (1995). Implicit and explicit learning of language. London. Academic Press

[6] Gairns, R. \& Redman, S. (1986). Working with words. A guide to teaching and learning vocabulary. Cambridge handbooks for language learners. Cambridge University Press.

[7] Heimlich, J. E. and Pittelman, S.D. (1986). Semantic Mapping: ClassroomApplications. Newark, Delaware: International Reading Association.

[8] Jonassen, D. H. (1993). Structural Knowledge: Techniques for Representing, Conveying, and Acquiring Structural Knowledge.

[9] Hillsdale, NJ: Lawrence Erlbaum Associates.

[10] Johnson, D., Pittelman, S. \& Heimlich, J. (1986). Semantic mapping. Reading Teacher, 39(8), 778-782.In Nguyen Ngoc Thuy, Viet Nam Retrieved from: http://www.litu.tu.ac.th/journal/FLLTCP/Proceeding/628.pdf

[11] McCarthy. (1990).Vocabulary Oxford: Oxford University press.

[12] Nation, I. S. P. (2001). Learning vocabulary in another language. Cambridge: Cambridge University Press

[13] Nation, P., \& Chung, T. (2009).Teaching and learning vocabulary. In International Journal of Educational Investigations. Vol.2, No.12, Dec.5015, PP. 54-72. Available online @ www.ijeionline.com

[14] Nation, I.S.P. (1990).Teaching and Learning Vocabulary. Boston, Massachusetts: Heinle \&Heinle Publishers.

[15] Omer,K. O. (2017). Effect of Using Semantic Maps Strategy on the Development of Vocabulary Learning for Sudanese Secondary Schools' Students. Ph.D. Thesis. Sudan University of Science \&Technology.

[16] Rahma,M.(2016).Teaching Vocabulary through Semantic Mapping Technique at the second year of SMP Muhammadiyah 3 Bandar Lampung.Unpublished M.A thesis. University of Bandar Lampung.

[17] Richards, Jack C. and Willy A. Renandya, (1986). Methodology inLanguage Teaching (An Anthology of Current Practice), Cambridge: Cambridge University Press. 
[18] Robb, L. (2000). Teaching Reading in the Middle School: A Strategic Approach to Teaching Reading that Improve Comprehension and Thinking. New York: scholastic professional books

[19] Sokmen, A. (1997). Current trends in teaching second language vocabulary. In N. Schmitt \& M, Michael (Eds.) (1997). Vocabulary: Description, acquisition and pedagogy (pp. 237- 257). Cambridge: Cambridge University Press.

[20] Thornbury, S. (2002). How to teach vocabulary. Harlow: Longman.

[21] Ur, P. (1996). A Course in language teaching: Practice and theory Cambridge:

\section{Appendix (1): Teachers 'Questionnaire}

\section{Part one: Personal Information:}

Please, insert $(\sqrt{ })$ in the appropriate space given:-
A) Age: a) $60-50$ ( ) b) $49-40$ ( ) c) $39-30$ ( ) d) $29-20$ ( )
B) Gender: Male ( ) Female ( )

\section{The academic Qualification:}

Intermediate Diploma ( ) BA ( ) higher diploma ( ) MA ( ) PHD ( )

\section{3-Teaching Experience:}

a) more than ten years ( ) b) ten years ( ) c)five years ( ) d) two years ( ) e)one year ( ) f)less than one year ( )

Part Two: Teachers' perspective about teaching vocabulary through semantic maps.

\begin{tabular}{|c|c|c|c|c|c|}
\hline Statements & $\begin{array}{l}\text { Strongly } \\
\text { agree }\end{array}$ & Agree & Uncertain & $\begin{array}{l}\text { Strongly } \\
\text { disagree }\end{array}$ & disagree \\
\hline $\begin{array}{l}\text { 1. Semantic Maps is a good teaching technique for } \\
\text { reviewing vocabulary lesson. }\end{array}$ & & & & & \\
\hline $\begin{array}{l}\text { 2. 10. The traditional presentation of vocabulary list } \\
\text { is found to be not effective in developing vocabulary } \\
\text { learning among secondary school students if } \\
\text { compared with semantic maps strategy. }\end{array}$ & & & & & \\
\hline $\begin{array}{l}\text { 3. Semantic Maps can help students remember the } \\
\text { words grouped in semantic sets for a longer time. }\end{array}$ & & & & & \\
\hline $\begin{array}{l}\text { 4. The grouping helps students remember the related } \\
\text { things. }\end{array}$ & & & & & \\
\hline $\begin{array}{l}\text { 5. Semantic Maps help the students retain the words } \\
\text { better. }\end{array}$ & & & & & \\
\hline $\begin{array}{l}\text { 6. Semantic maps assume that learners can easily } \\
\text { acquire a large vocabulary size. }\end{array}$ & & & & & \\
\hline 7. Semantic Maps improves the students' logic. & & & & & \\
\hline $\begin{array}{l}\text { 8. Semantic maps lead students to relate new words } \\
\text { to their own experiences and prior knowledge }\end{array}$ & & & & & \\
\hline $\begin{array}{l}\text { 9. Semantic Maps help the students recall the words } \\
\text { more easily. }\end{array}$ & & & & & \\
\hline $\begin{array}{l}\text { 10. It is easier to remember words if they are } \\
\text { grouped than learning unrelated words. }\end{array}$ & & & & & \\
\hline
\end{tabular}




\section{AUTHOR'S BIOGRAPHY}

Dr. Abdelrazig Abdelgani Mahil, got his Ph.D. in English Language from Alzaiem Alazhari University in (2017). He has an M.A in General Translation from University of Juba (2010) He alsogot a Post graduate Diploma in General Translation from University of Juba (2008). He awarded a bachelor (2004) and Intermediate Diploma degree in (1998) in Sharia'a and Law from Omdurman Islamic University. In addition to that he got an Intermediate Diploma in English Language from Nelain University in (2002) .He attended many courses and workshops in the field of English Language Teaching. He worked as an English teacher in Sudan Schools .He also worked as (ESP) Lecturer in Preparatory Year Program in several Saudi Universities. Currently he is (ESP) Lecturer at Posha Academy - Saudi Arabia - Riyadh City. He has published many research papers in different journals in the field of English Language Teaching and Translation.

Citation: Dr. Abdelrazig Abdelghani Mahil Ibrahim. "Impact of utilizing semantic maps strategy on the development of English language vocabulary learning for Saudi secondary schools' students" International Journal of Humanities Social Sciences and Education (IJHSSE), vol 4, no. 11, 2017, pp. 183-196. doi: http://dx.doi.org/10.20431/2349-0381.0411022.

Copyright: () 2017 Authors. This is an open-access article distributed under the terms of the Creative Commons Attribution License, which permits unrestricted use, distribution, and reproduction in any medium, provided the original author and source are credited. 